\title{
The effect of balneotherapy on body mass index, adipokine levels, sleep disturbances, and quality of life of women with morbid obesity
}

\author{
Fatmanur Aybala Koçak ${ }^{1}$ (D) Emine Eda Kurt ${ }^{1}$ (D) $\cdot$ Fikriye Milletli Sezgin $^{2}$ (D) $\cdot$ Senem Şaş $^{3}$ (D) $\cdot$ Figen Tuncay $^{1}$ (D) \\ Hatice Rana Erdem ${ }^{1}$ (D)
}

Received: 21 February 2020 / Accepted: 14 April 2020 / Published online: 6 May 2020

(C) ISB 2020

\begin{abstract}
To investigate the effect of balneotherapy on body mass index, adipokine levels, sleep disturbances, and quality of life in women with morbid obesity. Fifty-four women with morbid obesity were included in the study. The body mass indexes (BMI) and waist/ hip ratios (WHR) of the women were calculated. Subcutaneous fat thickness was measured using a *skinfold meter, and the percentage of adipose tissue was calculated. The *Pittsburgh Sleep Quality Index (PSQI) was used to assess sleep quality, and the Nottingham Health Profile (NHP) was used to assess quality of life. In addition to routine biochemical tests, leptin, adipokine, visfatin from blood, and cortisol from saliva samples were studied. Participants were given 15 sessions of balneotherapy for $20 \mathrm{~min}$ each. After treatment, the laboratory and clinical parameters of the participants were *reevaluated. There was no statistically significant difference of BMI, WHR, and percentage of adipose tissue between before and after treatment measurements $(p>0.05)$. There was a statistically significant improvement in PSQI and NSP scores $(p<0.001)$. The levels of blood glucose, leptin, and visfatin were significantly decreased, and adiponectin was significantly increased after treatment $(p=0.047$, $p<0.001, p<0.001$, and $p<0.001$, respectively).There was no statistically significant changes in salivary cortisol levels $(p=$ $0.848)$. Patients with diabetes showed a statistically significant decrease in glucose levels after treatment $(p=0.017)$. There was a statistically significant decrease in low-density lipoprotein cholesterol levels in patients with dyslipidemia compared with pretreatment $(p=0.018)$. Balneotherapy improves sleep and quality of life of women with morbid obesity. After balneotherapy, glucose, leptin, adiponectin, and visfatin levels may change positively.
\end{abstract}

Keywords Balneotherapy $\cdot$ Leptin $\cdot$ Visfatin $\cdot$ Adiponectin $\cdot$ Body mass index $\cdot$ Sleep quality $\cdot$ Quality of life

\section{Introduction}

Obesity is defined as abnormal or excessive fat accumulation according to the World Health Organization. Obesity is classified on the basis of body mass index (BMI): a BMI $>30 \mathrm{~kg} / \mathrm{m}^{2}$ is considered as obesity, and a BMI $>40 \mathrm{~kg} / \mathrm{m}^{2}$ is considered morbid obesity (World Health Organization Obesity Technical report series No: 894 Obesity: Preventing and managing the global epidemic. 2000). Obesity, in particular morbid obesity, results in a number of serious complications, such as type 2
Fatmanur Aybala Koçak

faybalarem@gmail.com

Emine Eda Kurt

eedakurt@gmail.com

Fikriye Milletli Sezgin

fikriyemilletli@hotmail.com

Senem Şaş

senemsas@gmail.com

Figen Tuncay

figentuncay3206@hotmail.com
Hatice Rana Erdem

hranaerdem@hotmail.com

1 Department of Physical Medicine and Rehabilitation, Ahi Evran University Faculty of Medicine, Bağbașı Mah. Șehit Sahir Kurutluoğlu Cad. No, 10040100 Kırșehir, Turkey

2 Department of Medical Microbiology, Ahi Evran University Faculty of Medicine, Bağbașı Mah. Șehit Sahir Kurutluoğlu Cad. No, 100 40100 Kırșehir, Turkey

3 Department of Physical Medicine and Rehabilitation, Ahi Evran University Education and Research Hospital, Bağbașı Mah. Șehit Sahir Kurutluoğlu Cad. No, 10040100 Kırșehir, Turkey 
diabetes mellitus (DM), peripheral vascular disease, disorders of the musculoskeletal system, and sleep disorders. Others, such as cancer, ischemic heart disease with myocardial infarction, or cerebral stroke, pose a serious threat to life. The last two complications are major causes of death of subjects with morbid obesity (Firszt-Adamczyk et al. 2016; World Health Organization Obesity Technical report series No: 894 Obesity: Preventing and managing the global epidemic. 2000). Quality of life (QoL) is an individual's assessment of their well-being and reflects physical and mental health and social relationships. In addition to all other health risks, obesity reduces QoL (Kolotkin and Andersen 2017).

All these morbidities associated with obesity are related to both the amount of adipose tissue and the functions of adipose tissue, because adipose tissue is not only an inactive organ that only stores lipids and energy. Numerous studies have shown that it is an active endocrine organ that secretes many substances, known as adipokines, which are involved in the regulation of several metabolic and physiologic processes (Bluher and Mantzoros 2015). In obesity, enlargement of adipose tissue has been linked to a dysregulation of adipokine secretion and adipose tissue inflammation (Fioravanti et al. 2015a). Since the discovery of their important role, adipokines have been used in the treatment of obesity and in outcome evaluations (Francisco et al. 2019).

The treatment of obesity is long term, difficult, and complex. There are many methods used such as diet treatments, exercise treatments, drug treatments, and surgical interventions (Ricci et al. 2016). These treatments include balneotherapy (Fioravanti et al. 2015a; Firszt-Adamczyk et al. 2016; Hanh et al. 2012; Jokic et al. 2018; Matsumoto 2018; Olah et al. 2011; Rapolienè 2016; Rosc et al. 2015), which traditionally involves immersion in mineral and/or thermal waters from natural springs, but may interchangeably be defined as balneological interventions with natural gases $\left(\mathrm{CO}_{2}\right.$, sulfur and radon, etc.), peloids (mud) and other traditional remedies (for example, hay), whereas hydrotherapy generally employs normal tap water for medical treatment (Fioravanti et al. 2017). Water with a temperature above $20{ }^{\circ} \mathrm{C}$ and a total mineral content exceeding $1 \mathrm{~g} / \mathrm{L}$ is called thermomineral water. These waters show their effects through mechanical, chemical, and thermal routes (Fioravanti et al. 2011). In addition, cure-like application positively affects physiologic and homeostatic processes and creates adaptive responses in the autonomic nervous, endocrine, and immune systems, providing general well-being (Fioravanti et al. 2011; Matsumoto 2018).

Balneotherapy has been used in the treatment of many musculoskeletal diseases for many years (Fioravanti et al. 2011). In the study conducted by Rapoliene (Rapoliene 2016), it was shown that balneotherapy decreased the amount of body fat. Similarly, in a study by Hanh et al. (Hanh et al. 2012), it was shown that BMI decreased after balneotherapy, and this effect lasted for 1 year. In the study conducted by Masiero et al. (Masiero et al. 2018), it was shown that hydrokinesitherapy in thermal setting in patients with obesity may determine pain relief, joint function improvement, and walking speed increase. In some other studies, the positive effects of balneotherapy on biochemical parameters and adipokines were shown in patients with obesity (Fioravanti et al. 2015a; Jokic et al. 2018; Olah et al. 2010; Olah et al. 2011; Rosc et al. 2015). However, there are some differences in the results of the studies. In the study conducted by Fioravanti et al., it was shown that balneotherapy decreased triglycerides, total cholesterol, low-density lipoprotein (LDL) cholesterol, glycemia, and serum levels of leptin and highsensitivity C-reactive protein (CRP) (Fioravanti et al. 2015a). In contradistinction, in the study conducted by Olah et al., it was shown that there was a difference between balneotherapy and control groups in post-treatment glucose level, which increased in the balneotherapy and decreased in the control group and changes from baseline of the remaining parameters (triglycerides, total cholesterol, LDL cholesterol, high-density lipoprotein (HDL) cholesterol, CRP, etc.) of the analyzed groups were not significant at any time point of comparison (Olah et al. 2011). In the study conducted by Rosc et al., it was shown that after balneotherapy a significant decrease in the concentration of CRP had occurred and insulin resistance (IR) was significantly reduced (Rosc et al. 2015).

There are some other studies showing the stress relieving, relaxing effects of balneotherapy on people without obesity (Latorre-Roman et al. 2015; Rapoliene et al. 2016; Yang et al. 2018). Some studies investigated the changes of cortisol levels after balneotherapy, which is a physiologic stress marker, in healthy or sub-healthy participants (Antonelli and Donelli 2018; Toda et al. 2006). In the study conducted by Toda et al., saliva samples were collected immediately before and after spa bathing from 12 healthy males, and it was shown that salivary cortisol levels decreased after spa bathing (Toda et al. 2006). In a review paper written by Antonelli and Donelli; main findings suggest that balneotherapy may have the potential to influence cortisol levels in healthy subjects in such a way as to improve stress resilience. Spa therapy with or without included mud/peloid therapy demonstrated the same potential to influence cortisol levels also in sub-healthy subjects (Antonelli and Donelli 2018).

The aim of this study was to investigate the effects of balneotherapy on BMI, body fat content, some routine blood tests (fasting blood glucose, insulin, total cholesterol, HDL cholesterol, LDL cholesterol, triglyceride, erythrocyte sedimentation rate (ESR), CRP, fibrinogen), adipokine levels (leptin, adiponectin, and visfatin), and cortisol levels. The secondary aim was to investigate the effects of balneotherapy on sleep quality and QoL in women with morbid obesity. 


\section{Participants and methods}

\section{Participant selection}

Fifty-four female participants with morbid obesity who presented to the physical medicine and rehabilitation outpatient clinics of the Kırşehir Ahi Evran University Training and Research Hospital (between September 2016 and April 2017) and who agreed to participate in the study were included. The inclusion criteria were as follows: to be between the ages of 18-70 years, to have a BMI $>40 \mathrm{~kg} / \mathrm{m}^{2}$, and to agree to participate in the study. In this study, to achieve homogenization and to exclude etiologic factors that might be variable depending on sex, the study group was composed of women only.

The exclusion criteria were as follows: the presence of any uncontrolled/decompensated systemic disease (hematologic, endocrine, rheumatologic, renal, cardiovascular, gastrointestinal, pulmonary disease); type $1 \mathrm{DM}$; active infection; history of malignancy; surgery or major trauma in the last year; being under a treatment for obesity (e.g., balneotherapy, exercise, medical treatment, surgery) in the last 3 months; pregnancy/ lactation; bleeding diathesis; severe psychological pathologies; and debility.

Before the study, permission was obtained from the local ethics committee. The participants were informed about the aim and method of the study and their written and oral consent was obtained. The study was conducted in accordance with the principles of the Declaration of Helsinki.

\section{Clinical measurement parameters}

\section{Demographic features}

Age, educational level, history of smoking and alcohol use, systemic diseases (hypertension, type $2 \mathrm{DM}$, coronary artery disease, and dyslipidemia), and family history of obesity were recorded.

\section{Clinical evaluation parameters}

Height (meters (m)) and body weight (kilograms (kg)) of participants were measured, and BMI $\left(\mathrm{kg} / \mathrm{m}^{2}\right)$ was calculated. Waist circumference (WC) (centimeters) and hip circumference (HC) (centimeters) were determined, and waist-to-hip ratio (WHR) was calculated by dividing these two values.

The amount and dispersion of body fat were evaluated by measuring the thickness of subcutaneous adipose tissue. Triple measurements were taken in four standard sites: biceps and triceps (limb) and subscapular and suprailiac skinfolds (trunk) using a Baseline ${ }^{\circledR}$ skinfold caliper (Fabrication Enterprises, Inc., New York, USA) (Lafayette Instrument Co. Indiana 47,903) (Baseline®Skinfold Caliper Operator’s
Manual for the Measurement of Subcutaneous Tissue and the conversion of this measurement to percentage of body fat. https://www.fab-ent.com/media/41_Instructions/121110_inst_ver10-11.pdf (access date:08.01.2020)). Three measurements at each skinfold site were performed, and the average of these was taken. These measurements were translated to body fat content as a percentage of body weight. Body fat content was estimated according to the Durnin and Womersley method, and body fat percentage was calculated using Siri's equation (Durnin and Womersley 1974).

Sleep quality was calculated using the Pittsburgh Sleep Quality Index (PSQI) (Buysse et al. 1989). The validity and reliability study of the scale has been shown (Ağargün et al. 1996). The PSQI is a measure assessing sleep quality and disturbance during the past month. Each item of the test is scored between 0 and 3 points. The scale is composed of seven subscales, and a total PSQI score of 0 to 21 is obtained by summing the subscale scores. A total PSQI score higher than five indicates a lower sleep quality.

The QoL of the participants was assessed using the Nottingham Health Profile (NHP) (Hunt et al. 1985), which consists of six subsections, and these sections can be scored separately. The sections are as follows: energy, pain, emotional reactions, sleep, social isolation, and physical activity. The NHP consists of 38 questions. Questions are answered as "yes" or "no". The answers have a specific scoring scale, and these scores are summed to assess the severity. The total score of each subcategory is 100 . Zero indicates the best health status; 100 indicates the worst health status. The validity and reliability of the NHP have been shown (Kücükdeveci et al. 2000).

All clinical measurements were performed twice by the same researcher before and immediately after the completion of the treatment ( 1 day after the last balneotherapy session, namely, 3 weeks later from the first session).

\section{Laboratory measurement parameters}

Both saliva and peripheral venous blood samples were taken in the morning time after $8 \mathrm{~h}$ of fasting.

\section{Determination of routine blood tests}

Routine blood tests (complete blood count, liver-kidneythyroid function tests, fasting blood glucose, insulin, total cholesterol, HDL cholesterol, LDL cholesterol, triglyceride, ESR, CRP, fibrinogen) were performed in the Biochemistry Laboratory of Kırșehir Ahi Evran University Training and Research Hospital. The IR was evaluated using the homeostasis model assessment (HOMA), which was calculated by using the following formula: Fasting plasma insulin 
(U/mL) x Fasting blood glucose $(\mathrm{mg} / \mathrm{dL}) / 405$ (normal value, $<2.5)$.

\section{Determination of serum leptin, adiponectin, and visfatin levels}

The samples were collected during the study and stored at $80^{\circ} \mathrm{C}$ on the day of the assay. Serum leptin, adiponectin, and visfatin levels were measured using an enzyme-linked immunosorbent assay (ELISA) kit (SunRed BioTechnology Co., Ltd., Catalog No; 201-12-1560, 201-12-1551, 201-12-0026, China) in accordance with the manufacturers' instructions. The assay range of the leptin, adiponectin, and visfatin ELISA kit was $0.2-60 \mathrm{ng} / \mathrm{mL}, 0.2-60 \mathrm{mg} / \mathrm{L}$, and $0.4-10 \mathrm{ng} /$ $\mathrm{mL}$, respectively. Serum samples were applied to wells in duplicate. A SPECTROstar nanomicroplate reader (BMG Labtech) was used for reading at $450 \mathrm{~nm}$, and data were processed using MARS software (BMG Labtech). Standard curves were generated using a four-parameter curve fitting equation, and leptin, adiponectin, and visfatin levels were calculated according to this curve. The resulting value was multiplied by the dilution factor of the sample to correct for the final concentration.

\section{Determination of salivary cortisol levels}

Saliva samples were collected using a Salivette® (Sarstedt). The salivettes were used according to the instructions provided by the manufacturer. Salivettes containing saliva were centrifuged at $2000 \mathrm{~g}$ for $10 \mathrm{~min}$, and the filtrates were stored frozen $\left(-80{ }^{\circ} \mathrm{C}\right)$. The samples were measured using an electrochemiluminescence immunoassay with a cortisol kit for saliva samples in an Cobas e601 analyzer (ROCHE Diagnostics, Germany).

All laboratory measurements were performed twice before and after treatment. Both blood and saliva samples (after completion of the treatment) were taken 1 day after the last balneotherapy session, in the morning, after $8 \mathrm{~h}$ of fasting.

\section{Treatment procedure}

Balneotherapy treatment was given in Kirșehir Terme Thermal Springs, which operates within the Kırșehir Ahi Evran University Training and Research Hospital Physical Medicine and Rehabilitation Department. The total mineralization content of the spa water, which has a temperature of $42 \pm 1{ }^{\circ} \mathrm{C}$, is $556 \mathrm{mg} / \mathrm{L}$ bicarbonate, $232 \mathrm{mg} / \mathrm{L}$ chloride, $226 \mathrm{mg} / \mathrm{L}$ calcium, $186.7 \mathrm{mg} / \mathrm{L}$ sodium, $98.3 \mathrm{mg} / \mathrm{L}$ sulfate, $58.43 \mathrm{mg} / \mathrm{L}$ silicate acid, $34.5 \mathrm{mg} / \mathrm{L}$ magnesium, and $2.6 \mathrm{mg} / \mathrm{L}$ fluoride. Balneotherapy was given to the participants in the form of a whole-body bath at 09.00 am for $20 \mathrm{~min}$. During the balneotherapy session, the participants did no activities (e.g., walking, aquatic exercise); they remained seated and received full-body immersion in the thermomineral water pool. The participants received a total of 15 sessions of treatment for 5 days during the week for 3 weeks. Daily routine activities were not changed. No other pharmacologic or nonpharmacologic treatment was administered to the participants, but pre-existing pharmacotherapy for type 2 DM or other diseases was not modified. No change in the diets of the participants such as calorie restriction was made.

\section{Statistics}

The Statistical Package for the Social Sciences (SPSS) 20 statistical package program (IBM Corporation, Armonk, NY, USA) was used for statistical analysis. Descriptive statistics are shown as mean \pm standard deviation and percentage. The Shapiro-Wilk test was used to determine whether the distribution of the variables was suitable for normal distribution. In repeated measurements, the paired sample $t$ test was used for the comparison of data matching normal distribution, and the Wilcoxon test was to compare data that did not match normal distribution. Statistical significance was accepted as $p<0.05$.

\section{Results}

The mean age of the participants was $58.35 \pm 9.84$ years. Some demographic and clinical characteristics of the participants are shown in Table 1.

There were no statistically significant differences between BMI, WHR, and body fat percentage before and after treatment (Table 2). PSQI and NHP scores (in all subsection scores of the NHP) improved significantly after balneotherapy $(p<0.05)$. The changes in all parameters are shown in Table 2.

According to the pre- and post-treatment comparisons, the levels of glucose, leptin, and visfatin were significantly decreased, and adiponectin was significantly increased after treatment $(p=0.047, p<0.001, p<0.001$, and $p<0.001$, respectively). There were no statistically significant changes in other laboratory parameters (Table 3 ).

The participants included in the study were divided into two groups as diabetic (type 2) and non-diabetic, and the values of laboratory parameters before and after treatment were compared. In the non-diabetic group, glucose values were not significantly changed, whereas in the diabetic group, glucose levels were significantly decreased after treatment $(p=0.017)$. The diabetic group also had a statistically significant increase in HDL cholesterol compared with pretreatment and a statistically significant decrease in LDL cholesterol compared with pre-treatment $(p=0.032$ and $p=$ 0.045 , respectively). Leptin, adiponectin, and visfatin levels were significantly different after treatment in both groups. 
Table 1 Some demographic and clinical characteristics of participants

\begin{tabular}{|c|c|}
\hline Age (year) $($ mean $\pm \mathrm{SD})($ minimum-maximum) & $58.35 \pm 9.84(36-70)$ \\
\hline \multicolumn{2}{|l|}{ Education $(n, \%)$} \\
\hline Illiterate & $9(16.7 \%)$ \\
\hline Primary school & $37(68.5 \%)$ \\
\hline Secondary school & $4(7.4 \%)$ \\
\hline High school or university & $4(7.4 \%)$ \\
\hline \multicolumn{2}{|l|}{ Smoking $(n, \%)$} \\
\hline Yes & $3(5.6 \%)$ \\
\hline No & $51(94.4 \%)$ \\
\hline \multicolumn{2}{|l|}{ Alcohol consumption $(n, \%)$} \\
\hline Yes & $0(0 \%)$ \\
\hline No & $54(100 \%)$ \\
\hline \multicolumn{2}{|l|}{ Family history of obesity $(n, \%)$} \\
\hline Yes & $16(29.6 \%)$ \\
\hline No & $38(70.4 \%)$ \\
\hline \multicolumn{2}{|l|}{ Hypertension $(n, \%)$} \\
\hline Yes & $33(61.1 \%)$ \\
\hline No & $21(38.9 \%)$ \\
\hline \multicolumn{2}{|l|}{ Coronary artery disease $(n, \%)$} \\
\hline Yes & $7(13 \%)$ \\
\hline No & $47(87 \%)$ \\
\hline \multicolumn{2}{|l|}{ Dyslipidemia $(n, \%)$} \\
\hline Yes & $22(40.7 \%)$ \\
\hline No & $32(59.3 \%)$ \\
\hline \multicolumn{2}{|l|}{ Diabetes mellitus (type 2) $(n, \%)$} \\
\hline Yes & $22(40.7 \%)$ \\
\hline No & $32(59.3 \%)$ \\
\hline
\end{tabular}

There was no statistically significant change in other laboratory parameters (Table 4).

The participants included in the study were divided into two other groups as those with and without dyslipidemia. The laboratory parameters of these groups before and after the treatment were compared. There was a statistically significant decrease in LDL cholesterol in the dyslipidemia group compared with pre-treatment $(p=0.018)$. Leptin, adiponectin, and visfatin levels were significantly different after treatment in both groups (Table 5).

\section{Discussion}

Obesity leads to increasing morbidity and mortality. Therefore, there is a need for studies on new treatment options that are easily accessible for patients with obesity. In the present study, the effect of the balneotherapy in the treatment of obesity was investigated. The results show that balneotherapy may cause some changes in some laboratory and clinical parameters of participants with morbid obesity, although the short-term assessments showed no effect on BMI, WHR, or body fat percentage. Some studies showing a decrease in BMI after balneotherapy are available in the literature. However, in some of these studies, dietary therapy was used in addition to balneotherapy treatment (Fioravanti et al. 2015a; Rosc et al. 2015). Therefore, it is difficult to say whether this effect belonged only to balneotherapy. In another study conducted by Rapoliene, the enrolled patients only received balneotherapy, and it was shown that BMI and body fat content were decreased after 15 balneotherapy sessions, and this effect was shown to continue after 4 months (Rapoliene 2016). The failure to detect a statistically significant change in BMI, WHR, and body fat percentage in the present study may be related to the fact that the second evaluation of the study was performed immediately after the end of treatment.

Although no change was observed in body measurements, statistically significant changes in adipokine levels were observed, which may suggest that balneotherapy affects the fat tissue. The adipocytes or adipose tissue macrophages produce adipokines which induce a low-grade chronic inflammatory state that could play a central role in obesity-related cardiovascular complications and insulin resistance (Antuna-Puente et al. 2008). In the present study, some adipokine levels were examined, including leptin, adiponectin, and visfatin. Leptin acts as a signaling molecule of metabolic status and mediates some metabolic processes (energy homeostasis, neuroendocrine functions, etc.). Hyperleptinemia and leptin resistance are closely associated with type $2 \mathrm{DM}$. Indeed, lower circulating leptin levels are associated with improved insulin sensitivity and inflammation (Ghadge and Khaire 2019; Ragino et al. 2020). In the patients with obesity, the concentration of leptin in plasma is markedly increased and correlates with body fat mass (Matarese et al. 2007; Chait and den Hartigh 2020). It is thought that leptin may be an important mediator between obesity and the development of cardiovascular diseases (Ragino et al. 2020; Landecho et al. 2019).

Adiponectin is the "good adipokine," which is anti-diabetic, anti-atherogenic, and anti-inflammatory (Bluher and Mantzoros 2015; Ragino et al. 2020; Chait and den Hartigh 2020). In patients with morbid obesity, circulating levels of adiponectin are mostly low and decrease after weight gain, which induce insulin sensitivity. In fact, adiponectin stimulates glucose uptake via increasing the fatty acid oxidation and reducing the glucose synthesis in the liver and works as an endogenous insulin sensitizer (Francisco et al. 2019). Adiponectin protects vascular endothelium against atherogenic inflammation through multiple effects on the endothelium, so it is a potent anti-atherogenic factor (Lago et al. 2007). Adiponectin deficiency is related with coronary artery disease and hypertension. In addition, adiponectin plays a role in preventing metabolic and cardiovascular disease (Liang and Ye 2019). 
Table 2 Comparison of pre-treatment and post-treatment clinical parameters of participants

\begin{tabular}{|c|c|c|c|}
\hline & Pre-treatment & $\begin{array}{l}\text { Post- } \\
\text { treatment }\end{array}$ & $p$ \\
\hline Body mass index $\left(\mathrm{kg} / \mathrm{m}^{2}\right)($ mean $\pm \mathrm{SD})(\min -\max )$ & $\begin{array}{c}58.29 \pm 7.51 \\
(45.00-80.69)\end{array}$ & $\begin{array}{c}57.93 \pm 6.82 \\
(45.36-74.53)\end{array}$ & 0.445 \\
\hline Waist/hip ratio (mean $\pm \mathrm{SD}$ ) (min-max) & $\begin{array}{c}0.87 \pm 0.09 \\
(0.78-1.34)\end{array}$ & $\begin{array}{c}0.87 \pm 0.07 \\
(0.78-1.21)\end{array}$ & 0.740 \\
\hline Body fat percentage $(\%)($ mean \pm SD) (min-max) & $\begin{array}{c}45.10 \pm 3.53 \\
(35.90-53.00)\end{array}$ & $\begin{array}{c}45.01 \pm 3.69 \\
(35.80-53.00)\end{array}$ & 0.612 \\
\hline Pittsburg sleep quality index (mean $\pm \mathrm{SD}$ ) (min-max) & $\begin{array}{l}7.44 \pm 4.54 \\
(0-18)\end{array}$ & $\begin{array}{l}4.20 \pm 3.32 \\
(0-14)\end{array}$ & $<0.001 *$ \\
\hline NHP-energy (mean \pm SD) (min-max) & $\begin{array}{l}61.15 \pm 2.81 \\
(0-100)\end{array}$ & $\begin{array}{l}31.34 \pm 27.88 \\
(0-100)\end{array}$ & $<0.001 *$ \\
\hline NHP-pain (mean \pm SD) (min-max) & $\begin{array}{l}58.92 \pm 29.95 \\
(0-100)\end{array}$ & $\begin{array}{l}28.19 \pm 24.71 \\
(0-100)\end{array}$ & $<0.001 *$ \\
\hline NHP-emotional reactions $($ mean $\pm \mathrm{SD})($ min-max) & $\begin{array}{l}35.08 \pm 3.36 \\
(0-100)\end{array}$ & $\begin{array}{l}20.58 \pm 28.47 \\
(0-100)\end{array}$ & $<0.001 *$ \\
\hline NHP-sleep $($ mean \pm SD) (min-max) & $\begin{array}{l}46.59 \pm 37.86 \\
(0-100)\end{array}$ & $\begin{array}{l}14.51 \pm 20.81 \\
(0-100)\end{array}$ & $<0.001 *$ \\
\hline NHP-social isolation $($ mean $\pm \mathrm{SD})(\min -\mathrm{max})$ & $\begin{array}{l}25.71 \pm 36.14 \\
(0-100)\end{array}$ & $\begin{array}{l}11.06 \pm 24.61 \\
(0-100)\end{array}$ & $<0.001 *$ \\
\hline NHP-physical activity (mean \pm SD) (min-max) & $\begin{array}{l}65.41 \pm 28.41 \\
(0-100)\end{array}$ & $\begin{array}{l}29.92 \pm 34.37 \\
(0-100)\end{array}$ & $<0.001 *$ \\
\hline
\end{tabular}

NHP Nottingham Health Profile, $S D$ standard deviation. ${ }^{*} p<0.05$ is statistically significant

Visfatin is an adipokine that is increased in obesity, insulin resistance, type $2 \mathrm{DM}$, and other pro-inflammatory states. It is responsible for the endothelial dysfunction that may cause progression of atherosclerosis. So, it becomes a risk factor for cardiovascular diseases (Liang and Ye 2019; Ragino et al. 2020; Landecho et al. 2019).

In summary, leptin and visfatin show pro-inflammatory and pro-atherogenetic activities, whereas adiponectin exerts anti-inflammatory and anti-atherogenetic effects (Matarese et al. 2007). The results of the present study show that balneotherapy decreased levels of leptin and visfatin and increased levels of adiponectin in all participants. In the study conducted by Fiovaranti et al., serum leptin levels showed a decrease after balneotherapy, whereas there were no significant changes in adiponectin levels. Serum visfatin showed a significant decrease in patients without diabetes and a slight but non-significant increase in patients with diabetes (Fioravanti et al. 2015a). However, the study population was composed of only males; by contrast, the present study was conducted only in females. In another study conducted by Fiovaranti et al., authors aimed to assess whether a cycle of mud-bath therapy influences the serum levels of adiponectin, resistin, and visfatin in patients with knee osteoarthritis (Fioravanti et al. 2015b). At the end of the mud-bath therapy, serum adiponectin and resistin levels showed a significant decrease, while no significant modifications of visfatin were found. But the mean BMI of the patients was $26.09 \pm 3.40 \mathrm{~kg} /$ $\mathrm{m}^{2}$, and having obesity was also one of the exclusion criteria of that study. Therefore, the results of that study may have been different from the results of the present study.
On the other hand, the present study shows that balneotherapy may lower fasting blood glucose levels, especially in patients with diabetes, although it does not alter levels of insulin or insulin resistance. A decrease in glucose levels was seen in the study conducted by Fiovaranti et al. (Fioravanti et al. 2015a), and a decrease in HOMA-IR levels was shown in the study conducted by Rosc et al. (Rosc et al. 2015). There are also animal studies in the literature showing the positive effects of balneotherapy on glucose metabolism and diabetes-related pathologies (Galvez et al. 2018). Moreover, in the present study, the diabetic group also showed an increase in HDL cholesterol and a decrease in LDL cholesterol compared with pre-treatment. Also, in the group of patients who already had dyslipidemia, there was a decrease in LDL cholesterol levels. Similar to the present study, in the study conducted by Fiovaranti et al. (Fioravanti et al. 2015a), a decrease in LDL cholesterol levels in both the diabetic and non-diabetic groups was shown, but there were no changes in HDL cholesterol levels after balneotherapy. However, the authors did not mention the history of lipid disease, and the study population comprised only males, whereas the present study was conducted only in females as mentioned earlier. In a pilot study conducted by (Jokic et al. 2018) to evaluate the effect of balneotherapy on lipid status, the researchers showed that blood glucose, triglyceride, total cholesterol, and LDL cholesterol levels decreased, but HDL cholesterol levels did not change. However, the number of patients included in that study was very small.

Another purpose of the present study was to determine the effects of balneotherapy on cortisol levels because it is 
Table 3 Comparison of pre-treatment and post-treatment laboratory parameters of participants

\begin{tabular}{|c|c|c|c|}
\hline & Pre-treatment & Post-treatment & $p$ \\
\hline Glucose (mean $\pm \mathrm{SD})(\min -\max )$ & $\begin{array}{l}102.85 \pm 27.55 \\
(70.00-217.00)\end{array}$ & $\begin{array}{l}97.61 \pm 21.34 \\
(72.00-204.00)\end{array}$ & $0.047 *$ \\
\hline Insulin $($ mean $\pm \mathrm{SD})($ min-max) & $\begin{array}{c}11.82 \pm 8.69 \\
(1.90-54.98)\end{array}$ & $\begin{array}{l}12.46 \pm 8.74 \\
(4.07-51.48)\end{array}$ & 0.163 \\
\hline HOMA-IR $(\mathrm{mg} / \mathrm{dL})($ mean $\pm \mathrm{SD})(\min -\max )$ & $\begin{array}{l}3.08 \pm 2.67 \\
(0.90-15.30)\end{array}$ & $\begin{array}{l}2.99 \pm 2.07 \\
(1.10-13.09)\end{array}$ & 0.722 \\
\hline Total cholesterol $($ mean $\pm \mathrm{SD})(\min -\mathrm{max})$ & $\begin{array}{l}186.55 \pm 36.77 \\
(77.00-269.00)\end{array}$ & $\begin{array}{l}182.06 \pm 31.87 \\
(103.00-259.00)\end{array}$ & 0.348 \\
\hline HDL cholesterol (mean $\pm \mathrm{SD})(\min -\max )$ & $\begin{array}{l}45.99 \pm 11.15 \\
(9.10-81.00)\end{array}$ & $\begin{array}{l}47.26 \pm 10.72 \\
(12.40-81.00)\end{array}$ & 0.754 \\
\hline LDL cholesterol (mean $\pm \mathrm{SD})($ min-max) & $\begin{array}{l}112.15 \pm 30.76 \\
(65.00-178.00)\end{array}$ & $\begin{array}{l}102.96 \pm 23.87 \\
(56.00-154.00)\end{array}$ & 0.210 \\
\hline Triglyceride (mean $\pm \mathrm{SD})$ (min-max) & $\begin{array}{l}162.92 \pm 80.40 \\
(51.00-421.00)\end{array}$ & $\begin{array}{l}154.65 \pm 77.48 \\
(57.00-485.00)\end{array}$ & 0.614 \\
\hline $\mathrm{CRP}($ mean $\pm \mathrm{SD})(\min -\max )$ & $\begin{array}{l}0.43 \pm 0.33 \\
(0.02-1.37)\end{array}$ & $\begin{array}{l}0.43 \pm 0.32 \\
(0.01-1.24)\end{array}$ & 0.609 \\
\hline $\mathrm{ESR}(\operatorname{mean} \pm \mathrm{SD})(\min -\max )$ & $\begin{array}{l}9.79 \pm 5.95 \\
(1.00-26.00)\end{array}$ & $\begin{array}{l}9.36 \pm 6.13 \\
(1.00-21.00)\end{array}$ & 0.482 \\
\hline Fibrinogen (mean $\pm \mathrm{SD})(\min -\max )$ & $\begin{array}{l}246.33 \pm 67.47 \\
(26.00-380.00)\end{array}$ & $\begin{array}{l}256.00 \pm 57.64 \\
151.00-400.47)\end{array}$ & 0.590 \\
\hline Leptin $($ mean \pm SD) (min-max) & $\begin{array}{c}9.50 \pm 5.77 \\
(4.40-34.20)\end{array}$ & $\begin{array}{l}7.47 \pm 4.89 \\
(3.00-29.90)\end{array}$ & $<0.001 *$ \\
\hline Adiponectin (mean $\pm \mathrm{SD})(\min -\max )$ & $\begin{array}{l}5.66 \pm 4.28 \\
(3.00-23.60)\end{array}$ & $\begin{array}{l}7.91 \pm 5.84 \\
(3.70-35.30)\end{array}$ & $<0.001 *$ \\
\hline Visfatin (mean \pm SD) (min-max) & $\begin{array}{l}2.15 \pm 1.65 \\
(1.10-12.60)\end{array}$ & $\begin{array}{l}1.18 \pm 1.09 \\
(0.60-7.90)\end{array}$ & $<0.001 *$ \\
\hline Cortisol (mean $\pm \mathrm{SD})$ (min-max) & $\begin{array}{l}0.34 \pm 0.18 \\
(0.05-0.83)\end{array}$ & $\begin{array}{l}0.34 \pm 0.19 \\
(0.05-0.90)\end{array}$ & 0.848 \\
\hline
\end{tabular}

$*_{p}<0.05$ is statistically significant

CRP C-reactive protein, ESR erythrocyte sedimentation rate, HDL high-density lipoprotein, HOMA-IR homeostatic model assessment of insulin resistance, $L D L$ low-density lipoprotein

believed that salivary cortisol levels accurately reflect the free fraction of cortisol in plasma; salivary levels were studied in the present study. In the study by Toda et al., the salivary cortisol levels of the healthy males showed a significant decrease after spa bathing (Toda et al. 2006). In a review investigating five studies, the main finding suggested that balneotherapy might have the potential to influence cortisol levels in healthy subjects (Antonelli and Donelli 2018). However, in the present study, there was no statistically significant change in cortisol levels, which may be related to the unhealthy state of morbid obesity.

Sleep is seen as an important variable of health that affects the individual's QoL and well-being. Adequate sleep is important for the renewal of the body, good functioning of brain functions, energy storage, good appearance, and protection against diseases. It has been determined that sleep time and quality of sleep affect memory, learning, performance, and metabolic and endocrine systems (Göktaş et al. 2015). A decrease in sleep time causes an increase in weight gain and obesity by disrupting the neurohormonal balance (Noh 2018). As a vicious circle, sleep disorders are very common in patients with obesity due to the morbidity of some obesity- related systemic diseases and also due to obstructive sleep apnea syndrome (World Health Organization Obesity Technical report series No: 894 Obesity: Preventing and managing the global epidemic. 2000; Göktaş et al. 2015). In a study conducted by Yang et al., it was shown that balneotherapy relieved mental stress, sleep disorders, and general health problems in sub-healthy people. In the present study, the sleep quality of the participants, as evaluated using the PSQI, was found to be very low before treatment. The improvement in scores after treatment shows that balneotherapy is effective for the sleep disorders of patients with obesity.

The QoL of people with obesity is lower compared with people with normal weight, due to both obesity itself and due to accompanying systemic diseases such as DM (Park 2017). An increase in QoL with weight loss has been shown in the literature (Kolotkin and Andersen 2017). Although the participants in the present study did not lose weight, positive wellbeing was observed after the treatment in all subsections of NHP scores indicating QoL. In the literature, improvements have been shown in parameters such as stress, fatigue, and poor perception of general health after balneotherapy in some 
Table 4 Comparison of pre-treatment and post-treatment laboratory parameters for participants with and without type 2 diabetes mellitus

Participants with type 2 diabetes mellitus $(n=22)$

\begin{tabular}{|c|c|c|c|c|c|c|}
\hline & $\begin{array}{l}\text { Pre-treatment } \\
(\text { mean } \pm \text { SD })\end{array}$ & $\begin{array}{l}\text { Post-treatment } \\
(\mathrm{mean} \pm \mathrm{SD})\end{array}$ & $p$ & $\begin{array}{l}\text { Pre-treatment } \\
(\text { mean } \pm \mathrm{SD})\end{array}$ & $\begin{array}{l}\text { Post-treatment } \\
(\text { mean } \pm \text { SD })\end{array}$ & $p$ \\
\hline Glucose & $122.00 \pm 33.12$ & $109.18 \pm 26.22$ & $0.017 *$ & $89.13 \pm 11.28$ & $86.84 \pm 19.02$ & 0.718 \\
\hline İnsulin & $14.08 \pm 12.73$ & $14.17 \pm 12.41$ & 0.643 & $10.29 \pm 3.81$ & $11.11 \pm 3.83$ & 0.123 \\
\hline HOMA-IR & $4.23 \pm 3.82$ & $3.54 \pm 2.84$ & 0.573 & $2.55 \pm 1.05$ & $2.31 \pm 0.93$ & 0.212 \\
\hline Total cholesterol & $185.90 \pm 38.50$ & $177.40 \pm 35.44$ & 0.064 & $187.00 \pm 36.15$ & $185.51 \pm 29.16$ & 0.907 \\
\hline HDL cholesterol & $42.27 \pm 10.89$ & $44.42 \pm 10.77$ & $0.032 *$ & $48.48 \pm 12.66$ & $48.91 \pm 10.64$ & 0.842 \\
\hline LDL cholesterol & $110.96 \pm 32.66$ & $98.59 \pm 23.28$ & $0.045^{*}$ & $109.75 \pm 34.93$ & $106.35 \pm 24.20$ & 0.970 \\
\hline Triglyceride & $174.00 \pm 102.86$ & $180.90 \pm 93.37$ & 0.576 & $142.56 \pm 54.76$ & $149.27 \pm 67.51$ & 0.842 \\
\hline CRP & $0.47 \pm 0.42$ & $0.52 \pm 0.37$ & 0.338 & $0.41 \pm 0.21$ & $0.37 \pm 0.26$ & 0.758 \\
\hline ESR & $10.00 \pm 6.77$ & $10.90 \pm 6.84$ & 0.657 & $8.38 \pm 6.23$ & $8.24 \pm 5.40$ & 0.262 \\
\hline Fibrinogen & $253.47 \pm 78.77$ & $272.96 \pm 62.78$ & 0.272 & $240.78 \pm 58.16$ & $241.16 \pm 49.36$ & 0.387 \\
\hline Leptin & $9.84 \pm 6.67$ & $7.76 \pm 5.72$ & $0.001 *$ & $9.26 \pm 5.18$ & $7.27 \pm 4.34$ & $<0.001 *$ \\
\hline Adiponectin & $6.13 \pm 5.20$ & $7.87 \pm 6.59$ & $0.001 *$ & $5.33 \pm 3.58$ & $7.94 \pm 5.40$ & $<0.001 *$ \\
\hline Visfatin & $2.34 \pm 2.42$ & $1.34 \pm 1.59$ & $<0.001 *$ & $2.03 \pm 0.84$ & $1.07 \pm 0.56$ & $<0.001 *$ \\
\hline Cortisol & $0.38 \pm 0.16$ & $0.37 \pm 0.21$ & 0.887 & $0.31 \pm 0.20$ & $0.32 \pm 0.18$ & 0.899 \\
\hline
\end{tabular}

${ }^{*} p<0.05$ is statistically significant

CRP C-reactive protein, ESR erythrocyte sedimentation rate, HDL high-density lipoprotein, HOMA-IR homeostatic model assessment of insulin resistance, $L D L$ low-density lipoprotein

other people (Latorre-Roman et al. 2015; Rapoliene et al. 2016; Yang et al. 2018). The present study shows that balneotherapy also makes similar improvements in patients with morbid obesity.
The limitations of this study include the absence of a control group. However, because normal values of anthropometric measurements and laboratory values are already known, a healthy control group without obesity was not included. The

Table 5 Comparison of pre-treatment and post-treatment laboratory parameters for participants with and without dyslipidemia

\begin{tabular}{|c|c|c|c|c|c|c|}
\hline & \multicolumn{3}{|c|}{ Participants with dyslipidemia $(n=22)$} & \multicolumn{3}{|c|}{ Participants without dyslipidemia $(n=32)$} \\
\hline & $\begin{array}{l}\text { Pre-treatment } \\
(\text { mean } \pm \text { SD })\end{array}$ & $\begin{array}{l}\text { Post-treatment } \\
(\text { mean } \pm \text { SD })\end{array}$ & $p$ & $\begin{array}{l}\text { Pre-treatment } \\
(\text { mean } \pm \text { SD })\end{array}$ & $\begin{array}{l}\text { Post-treatment } \\
(\text { mean } \pm \mathrm{SD})\end{array}$ & $p$ \\
\hline Glucose & $106.59 \pm 30.19$ & $105.50 \pm 27.66$ & 0.103 & $97.43 \pm 31.17$ & $92.68 \pm 14.66$ & 0.198 \\
\hline Insulin & $12.48 \pm 11.52$ & $11.13 \pm 4.34$ & 0.394 & $11.45 \pm 6.79$ & $13.17 \pm 10.37$ & 0.183 \\
\hline HOMA-IR & $3.21 \pm 3.25$ & $2.79 \pm 1.19$ & 0.570 & $3.02 \pm 2.34$ & $3.09 \pm 2.44$ & 0.962 \\
\hline Total cholesterol & $202.04 \pm 37.40$ & $190.35 \pm 32.49$ & 0.101 & $175.90 \pm 32.82$ & $175.92 \pm 30.56$ & 0.967 \\
\hline HDL cholesterol & $43.85 \pm 13.07$ & $44.91 \pm 11.06$ & 0.528 & $47.42 \pm 9.64$ & $48.14 \pm 12.59$ & 0.927 \\
\hline LDL cholesterol & $127.42 \pm 33.76$ & $107.52 \pm 25.07$ & $0.018^{*}$ & $99.70 \pm 22.87$ & $98.94 \pm 29.02$ & 0.773 \\
\hline Triglyceride & $194.25 \pm 93.65$ & $174.10 \pm 93.06$ & 0.408 & $142.50 \pm 64.59$ & $142.70 \pm 64.36$ & 0.780 \\
\hline CRP & $0.37 \pm 0.32$ & $0.35 \pm 0.32$ & 0.538 & $0.51 \pm 0.41$ & $0.49 \pm 0.31$ & 0.959 \\
\hline ESR & $10.09 \pm 6.04$ & $9.73 \pm 7.03$ & 0.659 & $12.09 \pm 16.55$ & $9.12 \pm 5.61$ & 0.244 \\
\hline Fibrinogen & $250.67 \pm 83.12$ & $252.12 \pm 65.40$ & 0.658 & $243.23 \pm 55.11$ & $258.36 \pm 53.52$ & 0.775 \\
\hline Leptin & $10.34 \pm 7.67$ & $8.70 \pm 6.47$ & $0.002 *$ & $8.92 \pm 4.06$ & $6.63 \pm 3.32$ & $<0.001 *$ \\
\hline Adiponectin & $6.86 \pm 6.19$ & $9.81 \pm 8.18$ & $0.001 *$ & $4.84 \pm 1.97$ & $6.63 \pm 3.03$ & $<0.001 *$ \\
\hline Visfatin & $2.60 \pm 2.41$ & $1.52 \pm 1.63$ & $<0.001 *$ & $1.85 \pm 0.75$ & $0.95 \pm 0.36$ & $<0.001 *$ \\
\hline Cortisol & $0.36 \pm 0.19$ & $0.37 \pm 0.20$ & 0.819 & $0.33 \pm 0.17$ & $0.32 \pm 0.19$ & 0.635 \\
\hline
\end{tabular}

${ }^{*} p<0.05$ is statistically significant

$C R P$ C-reactive protein, ESR erythrocyte sedimentation rate, $H D L$ high-density lipoprotein, HOMA-IR homeostatic model assessment of insulin resistance, $L D L$ low-density lipoprotein 
second limitation of this study was that only the short-term efficacy of balneotherapy was evaluated and there were no long-term outcomes. Studies including long-term results are needed to assess the sustainability of treatment effects. The third limitation was the lack of an evaluation of body composition using ultrasonography, dual-energy X-ray absorptiometry, or bioimpedance analysis. Body composition was evaluated using only simple measurements such as BMI, WHR, and total body fat percentage ratio. If a more advanced technological method had been used, a difference in body fat distribution might have been shown. The fourth limitation was the use of a single treatment method. The fifth limitation was that the sample size was not calculated before starting the study. Another limitation is that it was conducted only on women. We recommend for the future studies to have comparisons with other treatment methods (e.g., diet, exercise, tap water) and having long-term outcomes involving participants of both sexes.

\section{Conclusion}

Balneotherapy improves both quality of sleep and quality of life in women with morbid obesity. Balneotherapy may be recommended for the treatment of these problems. In this study, levels of glucose, HDL cholesterol, LDL cholesterol, leptin, adiponectin, and visfatin changed after balneotherapy. Thus, it is thought that balneotherapy may be a new adjunctive treatment for disorders of glucose and lipid metabolism.

Acknowledgments Authors would like to thank Neșe Çınar (MD, Assoc. Prof, specialist of endocrinology and metabolic diseases) for her valuable scientific contributions in the planning phase of this study. We as the authors would like to thank Kırșehir Ahi Evran University Scientific Research Projects Unit for supporting this project.

Funding information The laboratory material (leptin, adiponectin, visfatin and cortisol kits) used in this study were funded by the Scientific Research Projects Unit of Kırșehir Ahi Evran University by the project (TIP.A3.16.006).

\section{Compliance with ethical standards}

Conflict of interest The authors declared that they have no conflict of interest.

\section{References}

Ağargün M, Kara H, Anlar O (1996) Pittsburgh Uyku Kalitesi İndeksi'nin geçerliği ve güvenirliği. Türk Psikiyatri Derg 7(2): 107-111

Antonelli M, Donelli D (2018) Effects of balneotherapy and spa therapy on levels of cortisol as a stress biomarker: a systematic review. Int J Biometeorol 62(6):913-924. https://doi.org/10.1007/s00484-0181504-8
Antuna-Puente B, Feve B, Fellahi S, Bastard JP (2008) Adipokines: the missing link between insulin resistance and obesity. Diabetes Metab 34(1):2-11. https://doi.org/10.1016/j.diabet.2007.09.004

Baseline®Skinfold caliper operator's manual for the measurement of subcutaneous tissue and the conversion of this measurement to percentage of body fat. https://www.fab-ent.com/media/41 Instructions/12-1110_inst_ver10-11.pdf (access date:08.01.2020). https://www.fab-ent.com/media/41_Instructions/12-1110 inst ver10-11.pdf. Accessed 08.01.2020

Bluher M, Mantzoros CS (2015) From leptin to other adipokines in health and disease: facts and expectations at the beginning of the $21 \mathrm{st}$ century. Metabolism 64(1):131-145. https://doi.org/10.1016/j. metabol.2014.10.016

Buysse DJ, Reynolds CF, Monk TH, Berman SR, Kupfer DJ (1989) The Pittsburgh sleep quality index: a new instrument for psychiatric practice and research. Psychiatry Res 28(2):193-213. https://doi. org/10.1016/0165-1781(89)90047-4

Chait A, den Hartigh LJ (2020) Adipose tissue distribution, inflammation and its metabolic consequences, including diabetes and cardiovascular disease. Front Cardiovasc Med 7:22. https://doi.org/10.3389/ fcvm. 2020.00022

Durnin JV, Womersley J (1974) Body fat assessed from total body density and its estimation from skinfold thickness: measurements on 481 men and women aged from 16 to 72 years. Br J Nutr 32(1):77-97. https://doi.org/10.1079/bjn19740060

Fioravanti A, Adamczyk P, Pascarelli NA, Giannitti C, Urso R, Tolodziecki M, Ponikowska I (2015a) Clinical and biochemical effects of a 3-week program of diet combined with spa therapy in obese and diabetic patients: a pilot open study. Int J Biometeorol 59(7):783-789. https://doi.org/10.1007/s00484-014-0894-5

Fioravanti A, Cantarini L, Guidelli GM, Galeazzi M (2011) Mechanisms of action of spa therapies in rheumatic diseases: what scientific evidence is there? Rheumatol Int 31(1):1-8. https://doi.org/10.1007/ s00296-010-1628-6

Fioravanti A, Giannitti C, Cheleschi S, Simpatico A, Pascarelli NA, Galeazzi M (2015b) Circulating levels of adiponectin, resistin, and visfatin after mud-bath therapy in patients with bilateral knee osteoarthritis. Int J Biometeorol 59(11):1691-1700. https://doi.org/10. 1007/s00484-015-0977-y

Fioravanti A, Karagülle M, Bender T, Karagülle MZ (2017) Balneotherapy in osteoarthritis: facts, fiction and gaps in knowledge. Eur J Integrat Med 9:148-150. https://doi.org/10.1016/j.eujim.2017. 01.001

Firszt-Adamczyk A, Ruszkowska-Ciastek B, Adamczyk P, Szafkowski R, Firszt M, Ponikowska I, Moe K, Iwan-Zietek I, Goralczyk B, Goralczyk K, Rosc D (2016) Effect of a 3-week low-calorie diet and balneological treatment on selected coagulation parameters in morbidly obese patients. Adv Clin Exp Med 25(4):755-761. https:// doi.org/10.17219/acem/42414

Francisco V, Ruiz-Fernandez C, Pino J, Mera A, Gonzalez-Gay MA, Gomez R, Lago F, Mobasheri A, Gualillo O (2019) Adipokines: linking metabolic syndrome, the immune system, and arthritic diseases. Biochem Pharmacol 165:196-206. https://doi.org/10.1016/j. bcp.2019.03.030

Galvez I, Torres-Piles S, Ortega-Rincon E (2018) Balneotherapy, immune system, and stress response: a hormetic strategy? Int J Mol Sci 19(6). https://doi.org/10.3390/ijms19061687

Ghadge AA, Khaire AA (2019) Leptin as a predictive marker for metabolic syndrome. Cytokine 121:154735. https://doi.org/10.1016/j. cyto.2019.154735

Göktaş E, Çelik F, Özer H, Çıray Gündüzoğlu N (2015) The determination of the quality of sleep of the obese individuals. Dokuz Eylül Üniversitesi Hemșirelik Fakültesi Elektronik Dergisi 8(3):156-161

Hanh T, Serog P, Fauconnier J, Batailler P, Mercier F, Roques CF, Blin P (2012) One-year effectiveness of a 3-week balneotherapy program for the treatment of overweight or obesity. Evid Based Complement 
Alternat Med 2012:150839-150837. https://doi.org/10.1155/2012/ 150839

Hunt S, Mcewen J, Mckenna S (1985) Measuring health status: a new tool for clinicians and epidemiologists. J R Coll Gen Pract 35(275): $185-188$

Jokic A, Todic A, Markovic S, Antonic D (2018) The effect of balneotherapy on the nutritional status and lipid status parameters of the obese persons - pilot study. Bol Sociedad Españo Hidrol Med 33(S1):153-153. https://doi.org/10.23853/bsehm.2018.0644

Kolotkin RL, Andersen JR (2017) A systematic review of reviews: exploring the relationship between obesity, weight loss and healthrelated quality of life. Clin Obes 7(5):273-289. https://doi.org/10. 1111/cob.12203

Kücükdeveci A, McKenna S, Kutlay S, Gürsel Y, Whalley D, Arasıl T (2000) The development and psychometric assessment of the Turkish version of the Nottingham health profile. Int J Rehabil Res 23(1):31-38

Lago F, Dieguez C, Gomez-Reino J, Gualillo O (2007) The emerging role of adipokines as mediators of inflammation and immune responses. Cytokine Growth Factor Rev 18(3-4):313-325. https://doi.org/10. 1016/j.cytogfr.2007.04.007

Landecho MF, Tuero C, Valenti V, Bilbao I, de la Higuera M, Fruhbeck G (2019) Relevance of Leptin and other adipokines in obesityassociated cardiovascular risk. Nutrients 11(11). https://doi.org/10. 3390/nu11112664

Latorre-Roman PA, Rentero-Blanco M, Laredo-Aguilera JA, GarciaPinillos F (2015) Effect of a 12-day balneotherapy programme on pain, mood, sleep, and depression in healthy elderly people. Psychogeriatrics 15(1):14-19. https://doi.org/10.1111/psyg.12068

Liang W, Ye DD (2019) The potential of adipokines as biomarkers and therapeutic agents for vascular complications in type 2 diabetes mellitus. Cytokine Growth Factor Rev 48:32-39. https://doi.org/ 10.1016/j.cytogfr.2019.06.002

Masiero S, Vittadini F, Ferroni C, Bosco A, Serra R, Frigo AC, Frizziero A (2018) The role of thermal balneotherapy in the treatment of obese patient with knee osteoarthritis. Int J Biometeorol 62(2):243-252. https://doi.org/10.1007/s00484-017-1445-7

Matarese G, Mantzoros C, La Cava A (2007) Leptin and adipocytokines: bridging the gap between immunity and atherosclerosis. Curr Pharm Des 13:3676-3680

Matsumoto S (2018) Evaluation of the role of balneotherapy in rehabilitation medicine. J Nippon Med Sch 85(4):196-203

Noh J (2018) The effect of circadian and sleep disruptions on obesity risk. J Obes Metab Syndr 27(2):78-83. https://doi.org/10.7570/jomes. 2018.27.2.78
Olah M, Koncz A, Feher J, Kalmanczhey J, Olah C, Balogh S, Nagy G, Bender T (2010) The effect of balneotherapy on C-reactive protein, serum cholesterol, triglyceride, total antioxidant status and HSP-60 levels. Int J Biometeorol 54(3):249-254. https://doi.org/10.1007/ s00484-009-0276-6

Olah M, Koncz A, Feher J, Kalmanczhey J, Olah C, Nagy G, Bender T (2011) The effect of balneotherapy on antioxidant, inflammatory, and metabolic indices in patients with cardiovascular risk factors (hypertension and obesity)-a randomised, controlled, follow-up study. Contemp Clin Trials 32(6):793-801. https://doi.org/10. 1016/j.cct.2011.06.003

Park S (2017) Pathways linking obesity to health-related quality of life. Qual Life Res 26(8):2209-2218. https://doi.org/10.1007/s11136017-1565-X

Ragino YI, Stakhneva EM, Polonskaya YV, Kashtanova EV (2020) The role of secretory activity molecules of visceral adipocytes in abdominal obesity in the development of cardiovascular disease: a review. Biomolecules 10(3). https://doi.org/10.3390/biom10030374

Rapoliene L (2016) The effect of geothermal water on skin condition and body fat. Brit J Med Med Res 18(10):1-13. https://doi.org/10.9734/ bjmmr/2016/29892

Rapoliene L, Razbadauskas A, Salyga J, Martinkenas A (2016) Stress and fatigue management using balneotherapy in a short-time randomized controlled trial. Evid Based Complement Alternat Med 2016: 9631684-9631610. https://doi.org/10.1155/2016/9631684

Ricci MA, De Vuono S, Scavizzi M, Gentili A, Lupattelli G (2016) Facing morbid obesity: how to approach it. Angiology 67(4):391397. https://doi.org/10.1177/0003319715595735

Rosc D, Adamczyk P, Boinska J, Szafkowski R, Ponikowska I, Stankowska K, Goralczyk B, Ruszkowska-Ciastek B (2015) CRP, but not TNF-alpha or IL-6, decreases after weight loss in patients with morbid obesity exposed to intensive weight reduction and balneological treatment. J Zhejiang Univ Sci B 16(5):404-411. https://doi.org/10.1631/jzus.B1400219

Toda MMK, Nagasawa S, Kitamura K (2006) Change in salivary physiological stress markers by spa bathing. Biomed Res 27(1):11-14

World Health Organization Obesity Technical report series No: 894 Obesity: preventing and managing the global epidemic (2000) World Health Organization. Switzerland, Geneva

Yang B, Qin QZ, Han LL, Lin J, Chen Y (2018) Spa therapy (balneotherapy) relieves mental stress, sleep disorder, and general health problems in sub-healthy people. Int J Biometeorol 62(2):261272. https://doi.org/10.1007/s00484-017-1447-5 